Ahmed Mohmed Khalifa

\title{
Executive plan E-Management for Physical Education College(men) Alexandria University strategy
}

\author{
Ahmed Mohamed Khalifa \\ PhD from Department of Sports Management and Recreation \\ Faculty of Physical Education for men, Alexandria University , Egypt
}

\begin{abstract}
The purpose of this study was to design and propose an E-Management module for the Executive Plan in the Physical Education College by designing a web application coded with php, and MySQL Database, using the views and opinions form (56) of planners in the College and Alexandria University Quality Assurance Center, This study uses a personal interview and survey with the Director of Physical Education College Quality Assurance Unit, It also uses a survey containing (27) questions distributed in three sections, The survey reliability was approved by consulting (12) experts Directors of members of Alexandria University Quality Assurance Center, The researcher used Alpha Cronbach for calculating the survey reliability which give value of $(89,3)$, The study uses descriptive methodology with experimental methodology, Statistics processing was conducted by SPSS to measure means, standard deviation, Spearman Brown Stability Coefficient, and Pearson Correlation Coefficient, The researcher diagnosed the current situation for the manual plan process and reviewed Physical Education Strategy documents to complete a system analysis and then design and build a web application with appropriate all-inclusive functions for the Executive Plan,
\end{abstract}

Key Words: Executive plane, E-Management, Strategy.

Introduction

M Tanagement as an activity can be described differently and more precisely than other activities, that precision is not because it differs in characteristics from other human activities, but due to the fact that management is the responsible element for achieving goals and results that any organization is seeking in the society, (43:7)

Management progress is considered now as the title of development and property for nations, The development of any country is determined by; what is owned from human and economic resources,

But the question remains of how to manage these resources and their usage and how to ensure creative energy from the leaders armed with knowledge and experience and how to ensure that they know how to do their tasks in the most effective and efficient ways, (71:13)

Planning can be considered the most important requirement in management functions and it should be the priority among all functions because it is the frame that is needed to execute any task, The plan functions to define goals for other sectors and to guide and steer actions on those goals for the organizers 
and any involved individuals, Moreover, planning has the first priority over other administrative function like organizing, directing, controlling, It includes deciding among alternative methods of work and behavior for the entire organization and for each leader, administrative unit, department, and individual, (51:40)

Strategic planning defines the mission for the organization and determines strategic goals while it provides a design that enables the organization to work efficiently in an external environment, Strategic planning can be looked as providing a long term unifying planning focus in all strata of the organization, Strategic planning can be described as the pre preparation for intentional and strategic behaviors based on building environmental scenarios and future images of the interaction between the external environment and the organization, (61:68)

Shifting from classic management to E-Management isn't based in computers and internet and communication and other technical component, although they are important to E-Management, High quality management depends on an advanced management ideology and aware management leaders who are aiming to progress and support it with all requisite efforts to serve the beneficiaries and fulfil their demands with the highest quality commitment and professionalism, Shifting to this model of management requires not only changing administration to electronic tools and platforms, but to find individuals in society who are capable of dealing with technology and technologically literate, (10:36)
Sports management is a field that combines the practical and academic on a large scale, Sports management includes activities, individuals, organization that are related to sports in every imaginable configuration,(99:4)

Sports in this era has become an area controlled and managed by advanced technology, Without a doubt, the global progress that been seen in sports is not coincidental but the result of precise scientific planning based on the purposeful use of the latest technologies and tools for collecting, organizing, storing, processing, analyzing, and retrieving data,(92:7)

E-Management can be effective and efficient for its capacity to bring management up to speed with the technical and quantum progress in the field of information technology, escorted by continuous information processing, or information processing and communication, (31:35)

Technology is the organizing method that we use to access the historical and inherited knowledge in our field, Using this specialized system, we can reach more informed well-researched solutions for specific tasks, (14:270)

Strategy is very important and one of the most process misguided in management, strategy define the Main goals and enhance performance and the organization became more successful, and in the sports field. $(90,13)$

Lately more concern for Information management not only in the business aspect but in all aspects which required resources management due two reasons ,first the complication of management activities, second the development happened to decision make means 
Problem of study

Based on the researcher's experience working in the management field and designing computer software, reviewing the Faculty of Physical Education for Men in Alexandria University's Strategy 2015-2020, and reading some related research, he recognizes that most of the problems related to strategies and plans in universities and colleges in Egypt are not in the planning stage, Plans are placed in the right way but the problem usually come from the execution and progress monitoring of the plans and strategies, Monitoring and oversight is done manually or using traditional methods that take a long time and require great effort, These traditional methods lead to difficulty in collecting, reviewing, and classifying data immediately, These methods increase the difficulty of coordinating among departments that are responsible for the plan execution, The researcher also observes that most of the research on Emanagement and planning is academic and theoretical, with virtually no practical application, This observation is what has guided the researcher to his study in the Department of Management and Recreation, This study examines the demand for practical research about Executive planning using EManagement for Physical Education in the college (boys) based on the college's strategy, how to monitor progress toward establishing a solid base for EManagement, responsive follow up on the plan, identification of what is done and missing in the plan, as well as identifying obstacles and constraints related to plan's implementation and the decision making involved,

Strategic planning became one of the importance topics in the current era because the organization success will depend on achieving organization vision and goals this been discussed in (aldejwi) (2014) ,(Alsaady) (2007) and (Cho) (2018) about the agreement of EManagement aspects and it's employment in strategic planning.

Strategy analysis require to define the mission and goals for the organization clearly it showed be defined based in the available information. (85:6)

Aims of the Study:

Limiting of manual and paperwork procedures and converting to electronic mechanisms,

Designing and implementing a web application to follow up the Physical Education College (boys) plan, serve as an Assistant Editor/Reviewer for this journal. All Assistant Editors are named in the journal and on the website. If you

Question of the Study:

In view of the nature of the study objective, the researcher imposes its hypotheses formulation about the identity of the following:

1. What is the current mechanism that the college follows to execute the college plan?

2. How can the manual procedures for systematic information input be converted to a web application?

3. What are the appropriate assignments of privilege for each department in the college in the web application? 
4. How can the main goals for the college be achieved with an aim to achieve the strategic goals?

Terms of the study:

- E-Management: "The process of automating all tasks and activities of administration organization passed on all necessary information technologies aiming for accomplishing new administration target in paperless work and simplify procedures, Eliminate bureaucracy fast achievement with precise for the tasks and transaction for every administration to be ready for connecting with E-Government later."(47,34)

- Strategic planning:" The future vision for the organization, and draw their message and define her goals in the long term, and determine expected relation aspects between itself and the environment which contribute in chances declaration and surrounded Threats, strength and weakness based on her characteristic ,aiming to take strategic decisions to influence the organization in the long term therefore review and evaluation. $(61,68)$

- Operational plan:" Structured plans , including all activities and procedures related to achieving Initiatives and exciting projects in the Strategy, more over operational plan contain all the timings in detailed, in addition to the authorities and positions responsible for excusing the plan, as that operational plan can be done in specific period year or less." $(32,64)$
- Electronic Planning: "define what necessary to be currently done and in the future supported by massive information flow inside and outside the organization with the cooperation of the top and bottom of the hierarchy benefiting from Electronic network to face the unstable market and people demands and expected preferences through long term plans characterized by high flexibility and divided plans to portions and short term.(89:10)

- Decision Support System (DSS):

"Group of integrated Programs, ready-made bundles ,forms, processing tools, interact with information and data presenting suggested solutions, as it can merge many forms to build comprehensive form, serving management programs and dialogue production to allow decision maker to react with the system and direct communication to retrieve information benefiting in decision making semi-structured and structured.

Procedure of the study:

Study approach

In view of the nature of the study objective, the researcher used a descriptive methodology in the (survey method) that studied the phenomenon as it was in reality, paying attention to precise descriptions, using data collection about the phenomenon or the problem, to classify it and analyze it, As one of the objectives of the study is E-Management for the college executive 
plan, the researcher used also experimental methodology to test the study assumptions and verify achieving the study's goals, thus an experimental methodology provides the opportunity for translating goals from experiments, leading to precise conclusions.

Study sample:

Study sample represented in 56 individual been selected by Intentional method from Teaching staff who are members in Quality assurance units in Alexandria University and Physical Education College (boys) based in these conditions:

1. Teaching staff member.

2. Director or member of the Quality Assurance unit in Alexandria university.
3. Holding courses in strategic planning.

First group: Contained teaching staff from the Physical Education College (boys) Alexandria University who were members of the Quality Assurance unit in the college, These individuals were taking different courses in planning, aware of the college's strategy and plan,

Second group: This group includes the Director of the Quality Assurance unit in at Alexandria University and members of the Alexandria University Quality Assurance center, The researcher selected all members due to the few numbers of the study group.

Table (1)

Demographic data for Study sample

\begin{tabular}{|c|c|c|c|c|}
\hline Variable & Category & Number & Percent & Order \\
\hline \multirow{3}{*}{ Gender } & Male & 38 & $67.85 \%$ & 1 \\
\hline & Female & 18 & $32.15 \%$ & 2 \\
\hline & Total & 56 & \multicolumn{2}{|c|}{$100 \%$} \\
\hline \multirow{3}{*}{$\begin{array}{c}\text { Work } \\
\text { Designation }\end{array}$} & $\begin{array}{l}\text { Physical Education } \\
\text { College (boys) } \\
\text { Alexandria University }\end{array}$ & 31 & $55.36 \%$ & 1 \\
\hline & $\begin{array}{l}\text { Director of the } \\
\text { Quality Assurance at } \\
\text { Alexandria University }\end{array}$ & 25 & $44.64 \%$ & 2 \\
\hline & Total & 56 & \multicolumn{2}{|c|}{$100 \%$} \\
\hline
\end{tabular}


Tools of study:

The researcher used personal interviews and surveys to measure the required functions in the web application for the Executive Plan Strategy and to view the advantages that a web application would provide when implementing the application from the point of view of university and college planners,

\section{1- Personal interview:}

The researcher set up an interview with the Director of the Quality Assurance unit in the Physical Education College (boys) in his office on April 8, 2019 to know what methods were used in designing the strategic plan and the mechanisms and the methods in use in the current situation to determine and guide the executive plan, Based on this interview, the researcher was made aware of which function were needed in the web application,

\section{2- Survey}

The researcher designed an electronic survey to fulfill the study requirements and to identify appropriate components and functions of the web application and its design, The survey was revised by his supervisor on May 22, 2019, After revisions on the survey, the survey was administered to and completed by members of the Alexandria University Quality Assurance Center on July 17, 2019,

Survey validity:

Research used three methods:

1- Expert's validity: determining the basic axes of the survey after knowing the scientific references and the related studies, then designing survey axis and statements presented them to 10 experts quality assurance unit manager's, based on their opinion's and recommendations adjustment's been done to the final survey, below is the table for Experts view about the survey:

Table (2)

Expert's views about survey axis and statement's

\begin{tabular}{|c|c|c|c|c|}
\hline \multirow[t]{2}{*}{ Statement } & \multicolumn{2}{|c|}{ yes } & \multicolumn{2}{|c|}{ No } \\
\hline & $\mathbf{F}$ & Percentage & $\mathbf{F}$ & Percentage \\
\hline 4 & 43 & 76.79 & 13 & 23.21 \\
\hline 5 & 45 & 80.36 & 11 & 19.64 \\
\hline 6 & 52 & 92.86 & 4 & 7.14 \\
\hline 7 & 50 & 89.29 & 6 & 10.71 \\
\hline 8 & 45 & 80.36 & 11 & 19.64 \\
\hline 9 & 54 & 96.43 & 2 & 3.57 \\
\hline 10 & 56 & 100.00 & 0 & 0.00 \\
\hline 11 & 53 & 94.64 & 3 & 5.36 \\
\hline 12 & 52 & 92.86 & 4 & 7.14 \\
\hline 13 & 56 & 100.00 & 0 & 0.00 \\
\hline 14 & 52 & 92.86 & 4 & 7.14 \\
\hline 15 & 45 & 80.36 & 11 & 19.64 \\
\hline
\end{tabular}




\begin{tabular}{|l|l|c|l|c|}
\hline \multirow{2}{*}{ Statement } & \multicolumn{2}{|c|}{ yes } & \multicolumn{2}{c|}{ No } \\
\cline { 2 - 5 } & F & Percentage & & $\mathbf{3}$ \\
\hline $\mathbf{1 6}$ & $\mathbf{5 4}$ & $\mathbf{9 6 . 4 3}$ & $\mathbf{2}$ & $\mathbf{3 7}$ \\
\hline $\mathbf{1 7}$ & 48 & 85.71 & 8 & 14.29 \\
\hline $\mathbf{1 8}$ & 50 & 89.29 & 6 & 10.71 \\
\hline $\mathbf{1 9}$ & 53 & 94.64 & 3 & 5.36 \\
\hline $\mathbf{2 0}$ & 55 & 98.21 & 1 & 1.79 \\
\hline $\mathbf{2 1}$ & 51 & 91.07 & 5 & 8.93 \\
\hline $\mathbf{2 2}$ & 56 & 100.00 & 0 & 0.00 \\
\hline $\mathbf{2 3}$ & 52 & 92.86 & 4 & 7.14 \\
\hline $\mathbf{2 4}$ & 52 & 92.86 & 4 & 7.14 \\
\hline $\mathbf{2 5}$ & 49 & 87.50 & 7 & 12.50 \\
\hline $\mathbf{2 6}$ & 54 & 96.43 & $\mathbf{2}$ & 3.57 \\
\hline $\mathbf{2 7}$ & 47 & 83.93 & 9 & 16.07 \\
\hline
\end{tabular}

2- Survey Internal reliability validity:

Researcher calculated internal reliability validity through Alpha Cronbach coefficient for whole survery and for each Axil as presented in table below for the pilot sample.
Validity coefficient shown below in table (3) clarify that survey in General has high reliability $(0.90)$ which proof capability in achieving purpose of the study.

Table (3)

Internal reliability validity through Alpha Cronbach coefficient

$$
\mathrm{N}=12
$$

\begin{tabular}{|c|c|c|}
\hline Axil & Statements & Stability coefficient \\
\hline Program functions & 15 & 0.83 \\
& & 0.75 \\
\hline Program properties & 9 & 0.90 \\
\hline \multicolumn{2}{|c|}{ Survey } \\
\hline
\end{tabular}




\section{3- Construct Validity:}

Measure the objectives of the questionnaire achievement, clarifying the correlation between each axil in the study and the total score for each statement, that is done be verifying through calculating correlation coefficients for each point in the axil and the total score for the survey as in table
Results in table (5) represent value of revised Pearson correlation coefficient (spearman Brown) is high and statistically significant.

Based on that results survey is reliable and valid to be distributed and it's valid for survey outcome analysis, and answer the study questionnaire.

Table (4)

Correlation between Axils and survey

\begin{tabular}{|c|c|c|}
\hline Description & Pearson Correlation Coefficient & (sig) \\
\hline Program functions & $* * 0.98$ & $* * 0.00$ \\
\hline Program properties & $* * 0.96$ & $* * 0.00$ \\
\hline
\end{tabular}

Correlation is statistically significant at $(0.01 \geq \propto)$

Survey reliability:

splitting survey statements into two halves (even statements, odd statements) calculate Correlation coefficient between odd and even statements grades reach $(0.842)$ then correction of correlation coefficient by Spearman Brown equation so the coefficient value (0.914) adjusting length by Guttman value of (0.896) table (5).

Table (5)

Split half reliability coefficient

\begin{tabular}{|c|c|}
\hline Description & $\begin{array}{c}\text { Correlation coefficient with } \\
\text { whole grate }\end{array}$ \\
\hline Correlation coefficient between odd and even statments & 0.842 \\
\hline Spearman Brown coefficient for statements length & 0.914 \\
\hline Revised Spearman Brown coefficient for statement length variation & 0.914 \\
\hline Split Half for Guttman coefficient & 0.896 \\
\hline
\end{tabular}

Researcher used Statistical Package for Social Sciences (SPSS) to calculate :

- Spearman Brown coefficient: to define survey reliability by using Alpha Cronbach and Splitting halves.

- Mean and Standard deviation for survey statements to identify the high and low respond sample individual in each statement for the main variable in the study, knowing the response of the $n=12$ 
sample individual response to the survey axils.

- Pearson correlation coefficient: to measure the correlation between each axil and the survey as whole.

3- Web application design and implementation:

Based on completed survey feedback, review of the Physical Education College strategic documents, and examination of the manual Executive Plan mechanism, the researcher conducted a system analysis and designed web applications screens and implemented the functions of the application, to shift from handling the plan manually to an electronic mechanism, this process was conducted in three stages:

\section{Analysis \\ 2. Design \\ 3. Implementation}

The researcher input the plan goals and activities in the web application to demonstrate that hardcopy can be converted to softcopy electronic format through use of the application, The web application was activated after inputting the strategic goals and objectives for the college's strategy, After this work was completed, each department input its plan aligned with the strategic goals and objectives for the college,

Researcher used PHP Programming language because it's and open source designed for web applications.
Electronic application functions:

A. Input Plan information: Quality assurance unit will input the strategic goals for the College in the application, later every department will input his goals and activities to achieve the college strategic goals with time frame to achieve goals and objective for a year, after the department head will submit his department plan then the system will send the plan as a draft to Quality assurance unit to review and revise the plan if needed in co-operation with department head, after the plane reviewed and revised for Quality assurance unit for the college the plan will be transferred through the application to the College Dean for the final approval, once plan approved no edits can be done and plan ready to be executed any edits need to be done after plan approval that will require approval from Quality Assurance unit authentication.

B. Plan follow up: in the end of each quarter of the year each department have to $\log$ to the application and input what departments done in his plan as the scheduled time frame in case if not any mission or goals done they have to mention the reason.

C. Plan progress evaluation: after every department input his activities and goals the Quality assurance unit will review it and check the reasons for uncomplete activities or goals and fix this issues. 
Electronic application features:

1- Save effort and time in inputting the annual plan.

2- Easy access to all plan information and reports through the application.

3- Inclusiveness and connecting all college department through one network through application.

4- Security and confidentiality will be provided from the application through defining privilege for each user based in his position and role in the plan.
5- Saving and retrieval information from the system provided in the application all plans will be saved in the application data base.

6- Communications through the messages and alerts shown to users.

Discussing and reviewing survey outcome:

To explain study outcome and response the researcher used mean for the axils and statement for each axil.

Discussing and review first axil electronic application functions

Table (6)

Electronic application functions

\begin{tabular}{|c|c|c|c|c|c|c|c|c|}
\hline & \multirow{3}{*}{ Statement } & & & & & \multicolumn{3}{|c|}{$\mathrm{n}=56$} \\
\hline \multirow{2}{*}{ ser } & & \multicolumn{2}{|c|}{ Agree } & \multicolumn{2}{|c|}{ Disagree } & Standard & & \\
\hline & & $\mathrm{n}$ & $\%$ & $\mathrm{n}$ & $\%$ & deviation & Mean & Order \\
\hline 1 & $\begin{array}{l}\text { Electronic application will perform planning } \\
\text { through goals defining for each department } \\
\text { by the electronic application input each } \\
\text { department goals , mission with time frame }\end{array}$ & 42 & 75 & 14 & 25 & 0.43 & 0.75 & 14 \\
\hline 2 & $\begin{array}{l}\text { Department efficiency in achieving College } \\
\text { goals through the application which will } \\
\text { provide decentralization in planning by input } \\
\text { the annual plan for each department }\end{array}$ & 46 & 82.1 & 10 & 17.9 & 0.38 & 0.82 & 13 \\
\hline
\end{tabular}


Ahmed Mohmed Khalifa

\begin{tabular}{|c|c|c|c|c|c|c|c|c|}
\hline \multirow{2}{*}{ ser } & \multirow{2}{*}{ Statement } & \multicolumn{2}{|c|}{ Agree } & \multicolumn{2}{|c|}{ Disagree } & \multirow{2}{*}{$\begin{array}{l}\text { Standard } \\
\text { deviation }\end{array}$} & \multirow{2}{*}{ Mean } & \multirow{2}{*}{ Order } \\
\hline & & $\mathrm{F}$ & $\%$ & $\mathrm{~F}$ & $\%$ & & & \\
\hline 3 & $\begin{array}{l}\text { Electronic application will activate } \\
\text { departments role in accomplishing targets } \\
\text { and missions, updating learning and training } \\
\text { by the input missions to achieve this target }\end{array}$ & 51 & 91.1 & 5 & 8.9 & 0.28 & 0.91 & 8 \\
\hline 4 & $\begin{array}{l}\text { Electronic application will employ } \\
\text { organizing by designing users access based } \\
\text { on College hierarchy and specializations for } \\
\text { each department }\end{array}$ & 50 & 89.3 & 6 & 10.7 & 0.31 & 0.89 & 10 \\
\hline 5 & $\begin{array}{l}\text { The application will help Quality assurance } \\
\text { unit for effective planning by putting } \\
\text { Strategic goals and the special indicators for } \\
\text { the department plans and follow up with the } \\
\text { application }\end{array}$ & 54 & 96.4 & 2 & 3.6 & 0.18 & 0.96 & 3 \\
\hline 6 & $\begin{array}{l}\text { Quality assurance unit will direct and correct } \\
\text { and deviation for the department in case if it } \\
\text { happens supported by the application }\end{array}$ & 54 & 96.4 & 2 & 3.6 & 0.18 & 0.96 & 4 \\
\hline 7 & $\begin{array}{l}\text { Electronic application will be a useful tool } \\
\text { for the Dean and department head to be } \\
\text { aware of what is done and what isn't } \\
\text { accomplished in the plan by the generated } \\
\text { report from the system. }\end{array}$ & 55 & 98.2 & 1 & 1.8 & 0.13 & 0.98 & 1 \\
\hline 8 & $\begin{array}{l}\text { Plan follow up will be available anytime by } \\
\text { the application for each department with the } \\
\text { works done to achieve the goals }\end{array}$ & 53 & 94.6 & 3 & 5.4 & 0.22 & 0.94 & 5 \\
\hline
\end{tabular}


Ahmed Mohmed Khalifa

\begin{tabular}{|c|c|c|c|c|c|c|c|c|}
\hline \multirow{2}{*}{ ser } & \multirow{2}{*}{ Statement } & \multicolumn{2}{|c|}{ Agree } & \multicolumn{2}{|c|}{ Disagree } & \multirow{2}{*}{$\begin{array}{l}\text { Standard } \\
\text { deviation }\end{array}$} & \multirow{2}{*}{ Mean } & \multirow{2}{*}{ Order } \\
\hline & & $n$ & $\%$ & $\mathrm{n}$ & $\%$ & & & \\
\hline 9 & $\begin{array}{l}\text { Electronic application will ease the evaluation of } \\
\text { the plan objective and goals by the evidence of } \\
\text { accomplishing each mission and uploaded to the } \\
\text { application }\end{array}$ & 51 & 91.1 & 5 & 8.9 & 0.28 & 0.91 & 9 \\
\hline 10 & $\begin{array}{l}\text { Electronic application will have many properties } \\
\text { as providing statistics about the missions achieved } \\
\text { of objective which will ease the evaluation of the } \\
\text { plan through entire year }\end{array}$ & 55 & 98.2 & 1 & 1.8 & 0.13 & 0.98 & 2 \\
\hline 11 & $\begin{array}{l}\text { Assessment each quarter year will be one of the } \\
\text { application characteristic and end of year } \\
\text { evaluation for department plans to be aware of the } \\
\text { advantages and disadvantages. }\end{array}$ & 52 & 92.9 & 4 & 7.1 & 0.25 & 0.92 & 7 \\
\hline 12 & $\begin{array}{l}\text { College dean will be responsible for approving } \\
\text { plans and he will be the planning leader and take } \\
\text { the propitiate decisions to achieve goals }\end{array}$ & 34 & 60.7 & 22 & 39.3 & 0.49 & 0.60 & 15 \\
\hline 13 & $\begin{array}{l}\text { Decisions support system will be provided by } \\
\text { giving all information and indicators needed for } \\
\text { plans immediately and accuracy. }\end{array}$ & 53 & 94.6 & 3 & 5.4 & 0.22 & 0.94 & 6 \\
\hline 14 & $\begin{array}{l}\text { Right model of management by objective will be } \\
\text { represented by the Electronic application allowing } \\
\text { departments to put his plan and follow it to } \\
\text { achieve the objectives. }\end{array}$ & 48 & 85.7 & 8 & 14.3 & 0.35 & 0.85 & 12 \\
\hline 15 & $\begin{array}{l}\text { Electronic application will be a pattern for Total } \\
\text { quality management as it will enhance } \\
\text { performance continuously through direct follow } \\
\text { up and assessment for the plan in all stages by the } \\
\text { application }\end{array}$ & 50 & 89.3 & 6 & 10.7 & 0.31 & 0.89 & 12 \\
\hline & Balanced mean and Standard deviat & ion & the & & & 0.14 & & 89 \\
\hline
\end{tabular}

Mean is statistically significant at $(\alpha \leq 0.05)$ 
Table (6) represent the Functions of the Electronic application:

The weighted average for the first axil (functions of the electronic application) had value of (0.897619) with standard deviation (0.14) and mean (0.89) it corresponds Significant approval meaning the agreement about the electronic application, which means the belief of Alexandria University and Physical Education College of the importance of E-Management meeting the first strategic goal for the College "Advance the competition for the university by the creation of new learning environment based on integrated technical systems, the research notice during his study in the college the aim to use the advanced electronic systems by allowing the researcher to be the first researcher who

did online seminar presenting the frame of the PH.D frame in the first time of college history, establishing a website for the college providing some services for the students is another poof of the college attention to E-Management.

Table (6) show the agreement from the sample about the implementation of EManagement In the planning process for the college Which is consistent with (Aldejwi)(2015) Where was the benefit from the administration system in the colleges through applying EManagement systems $90 \%$.this also accords with opinions of (A.Alhyet) (2014) found out that High and middle level of management are convinced by the importance of the E-managements functions and its application,(Alshary)
(2011) suggested shifting from classic management to E-Management.

Highest Rank Statement:

First statement had agreement from the majority of study sample is" Electronic application will be a useful tool for the Dean and department head to be aware of what is done and what isn't accomplished in the plan by the generated report from the system." With standard deviation (0.13) and mean (0.98) with agreement of 55 individual from study sample, researcher accord to this opinion that electronic application will provide all information needed for the department plans to the Dean and also information will available for department head to review and follow the plan.

In this regard (Fatih)(2008) that advantages based in Electronic application represented in provide information electronically in all management levels.

Another paragraph sharing highest agreement among study sample responders is "Electronic application will have many properties as providing statistics about the missions achieved of objective which will ease the evaluation of the plan through entire year" with standard deviation (0.13) and Mean (0.98) representing the high agreement of responders for evaluation and assessment to be Electronic by the application through evaluating the missions achieved in the plan paperless. Researcher refer this to study sample aware about the importance of evaluation and assessment and providing 
information weather plan mission achieved or not.

This accord with the opinion of (Edries) (2011) E-Management will provide necessary information with speed and accuracy (AlShahry) (2011) agreed that E-Management that depends in networking and database will give access to employ to have information in any time and any place.

Lowest Rank statement:

The statement " College dean will be responsible for approving plans and he will be the planning leader and take the propitiate decisions to achieve goals" come in the last place among the study sample with standard deviation(0.49)

mean (0.60) which is representing the role of effective leadership in achieving goals.
The research view is the electronic application will provide database for the dean he can use it as a support for his administrative decision making, in that field (Radwan) concluded the EManagement limit the decision make constraints by providing information and connecting it. Study of (Al Baz) (2003) accord to this opinion in the environment of E-Management system Managers and leaders have few moments to take decision assuming that decision will be supported by stored information so decision make will not be same routine or from higher management.

This is also according in the opinion of (Oke,Lorne) (97) (2003) in order for successful planning for information technology the High management should be involved for management process Quality.

Shape (1)

Study sample response for first axil
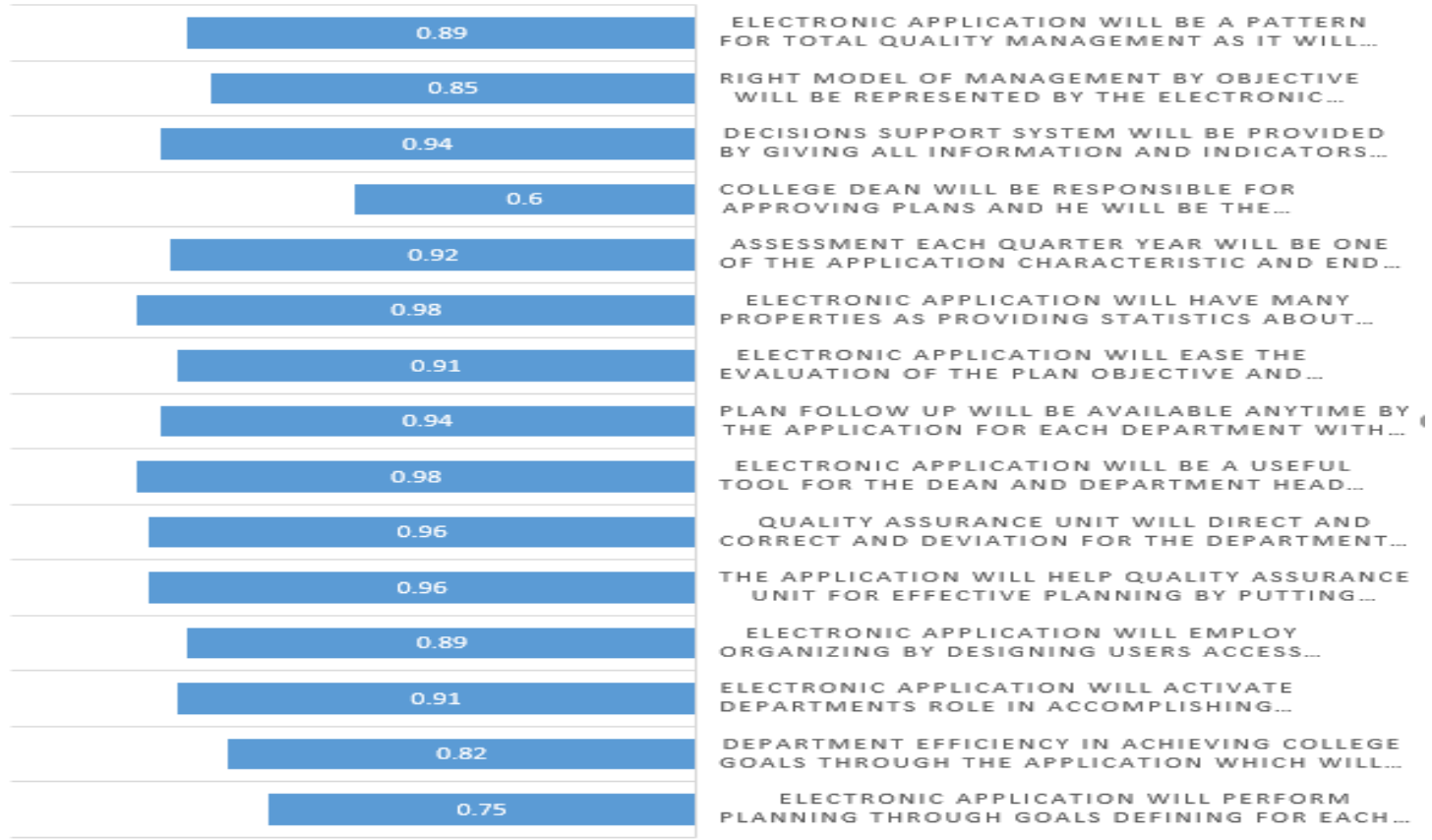
Discussing and review second axil electronic application features

Table (7)

$\mathrm{n}=56$

Electronic application Features

\begin{tabular}{|c|c|c|c|c|c|c|c|c|}
\hline \multirow{2}{*}{ Ser } & \multirow{2}{*}{ Statement } & \multicolumn{2}{|c|}{ Agree } & \multicolumn{2}{|c|}{ Disagree } & \multirow{2}{*}{$\begin{array}{l}\text { Standard } \\
\text { deviation }\end{array}$} & \multirow{2}{*}{ Mean } & \multirow{2}{*}{ Order } \\
\hline & & $\mathrm{F}$ & $\%$ & $F$ & $\%$ & & & \\
\hline 1 & $\begin{array}{l}\text { Electronic application will simplify } \\
\text { Plan Input procedure and follow up } \\
\text { which will save effort and time. }\end{array}$ & 54 & 96.4 & 2 & 3.6 & 0.18 & 0.96 & 3 \\
\hline 2 & $\begin{array}{l}\text { Plan accessibility will be granted } \\
\text { through the Electronic application to } \\
\text { all plan details easing plan report } \\
\text { printing and performance report }\end{array}$ & 55 & 98.2 & 1 & 1.8 & 0.13 & 0.98 & 1 \\
\hline 3 & $\begin{array}{l}\text { Flexibility and possibility to revise } \\
\text { and edit electronic application to } \\
\text { enhance effectiveness and efficiency } \\
\text { after the application trial. }\end{array}$ & 54 & 96.4 & 2 & 3.6 & 0.18 & 0.96 & 4 \\
\hline 4 & $\begin{array}{l}\text { Departments plan information } \\
\text { storage by Electronic application to } \\
\text { have access anytime with archiving } \\
\text { proof of goals achievement. }\end{array}$ & 55 & 98.2 & 1 & 1.8 & 0.13 & 0.98 & 2 \\
\hline 5 & $\begin{array}{l}\text { Electronic application will connect all } \\
\text { plan by one network provided by the } \\
\text { application. }\end{array}$ & 51 & 91.1 & 5 & 8.9 & 0.28 & 0.91 & 8 \\
\hline 6 & $\begin{array}{l}\text { Safety and security will be managed } \\
\text { by the Electronic application by } \\
\text { assigning a username and password } \\
\text { for each user who authorized to use } \\
\text { the application }\end{array}$ & 52 & 92.9 & 4 & 7.1 & 0.25 & 0.92 & 7 \\
\hline 7 & $\begin{array}{l}\text { Accuracy will be one of the Electronic } \\
\text { application characteristics by } \\
\text { providing by input months of the } \\
\text { implementation and percentage of } \\
\text { achievement every month }\end{array}$ & 53 & 94.6 & 3 & 5.4 & 0.22 & 0.94 & 6 \\
\hline
\end{tabular}




\begin{tabular}{|c|c|c|c|c|c|c|c|c|}
\hline \multirow{2}{*}{ Ser } & \multirow{2}{*}{ Statement } & \multicolumn{2}{|c|}{ Agree } & \multicolumn{2}{|c|}{ Disagree } & \multirow{2}{*}{$\begin{array}{l}\text { Standard } \\
\text { deviation }\end{array}$} & \multirow{2}{*}{ Mean } & \multirow{2}{*}{ Order } \\
\hline & & $\mathrm{n}$ & $\%$ & $\mathrm{~N}$ & $\%$ & & & \\
\hline 8 & $\begin{array}{l}\text { Electronic application will provide } \\
\text { transparency through the department } \\
\text { input for his mission accomplished or } \\
\text { not or even postpended end of every } \\
\text { quarter year }\end{array}$ & 54 & 96.4 & 2 & 3.6 & 0.18 & 0.96 & 5 \\
\hline 9 & $\begin{array}{l}\text { Do you believe in case of electronic } \\
\text { application trial success in Executive } \\
\text { plan E-Management for Physical } \\
\text { Education College(men) Alexandria } \\
\text { University strategy it can be } \\
\text { published and generalize and get } \\
\text { benefited by other Colleges and } \\
\text { institutes in Alexandria university }\end{array}$ & 48 & 85.7 & 8 & 14.3 & 0.35 & 0.85 & 9 \\
\hline \multicolumn{6}{|c|}{ Balanced mean and Standard deviation for the axil } & 0.11 & \multicolumn{2}{|c|}{0.94} \\
\hline
\end{tabular}

Mean is statistically significant at $(\alpha \leq 0.05)$

The weighted average for the Second axil (features of the electronic application) had value of (0.94) with standard deviation $(0.11)$ reflecting that electronic application features been agreed in high percentage from responders proving their convection about the features and the advantages provided by electronic application against the manual or paper work indisputable.

Researcher point of view electronic applications will provide many features is not available in the paper work, these features can be used in management process to enhance and speed

Performance with low coast and minor errors and cut many steps required in paper work.
The pervious mention accords with opinions of (Al Hassan) (2009) dependence on modern Technology programs in saving effort and time, and cut procedures as possible and get benefited from information technology in enhance quality of modern management, (Masoud Bin Mohamed Al Namir \& Others) confirm that EManagement Enhance organization performance and simplify procedures and provide data and information to all Beneficial's Electronically 24/7 in location easy and simple representing rationalizing and saving time and effort and money, more over E-Management characteristic speed and accuracy in achieving work. 
Highest rank statement:

The Highest agreement for the statement " Plan accessibility will be granted through the Electronic application to all plan details easing plan report printing and performance report" with standard deviation (0.13) and Mean (0.98) with agreement of 55 responders.

Researcher accords with study sample opinion that the most important advantage that will provided by the electronic application is accessibility to information and data processing paying attention to define privilege for each user that is also been agreed by (Alghasany) (2005) that electronic application will enhance performance by allowing access to information for whom it needed and easy collection information by it presence in the intranet with less effort and electronic search tools.

Second paragraph sharing the majority of agreement is " Departments plan information storage by Electronic application to have access anytime with archiving proof of goals achievement."

Researcher accords with this opinion because electronic application will provide reports upload to the system and save goals objectives and missions in this regard (Al Halafoey) (2006) mention that E-Management implementation will provide easy data save and store information from the nature disasters by keeping backup file. Also (Hussien) (2009) pointed that many of paper work in the classic system will be lost due to damage for long storing, Electronic files and folders will be securely saved safely from damages in specific place in the network server for the organization

lowest rank statement:

The lowest agreement among responders were in statement "Do you believe in case of electronic application trial success in Executive plan E-Management for Physical Education College(men) Alexandria University strategy it can be published and generalize and get benefited by other Colleges and institutes in Alexandria university "

with standard deviation (0.35) and Mean $(0.85)$ with agreement of 48 responders. Researcher see that this reflect agreement to generalize the electronic application in the other colleges and institutes in Alexandria university in Quality Assurance units now EManagement is not an option it a decision should be made and applied to all college's and institute's in Alexandria university that was referred by (Al Agha) (2012) that employing New technology aspects in the learning process, and enhance the academic staff for use of using electronic application available in this field, and connect college's in different locations together in same field (Al Shaqasi) (2008) that easing communication between management levels and simplifying networking between ministries and other external organization and assemble all ministries services in one website .(Al Baz) (2003) accords with this opinion that E-Management implementation will work in improving relations aspects inside organization and enhance this relations between Electronic 
Shape (2)

Study sample response for second axil

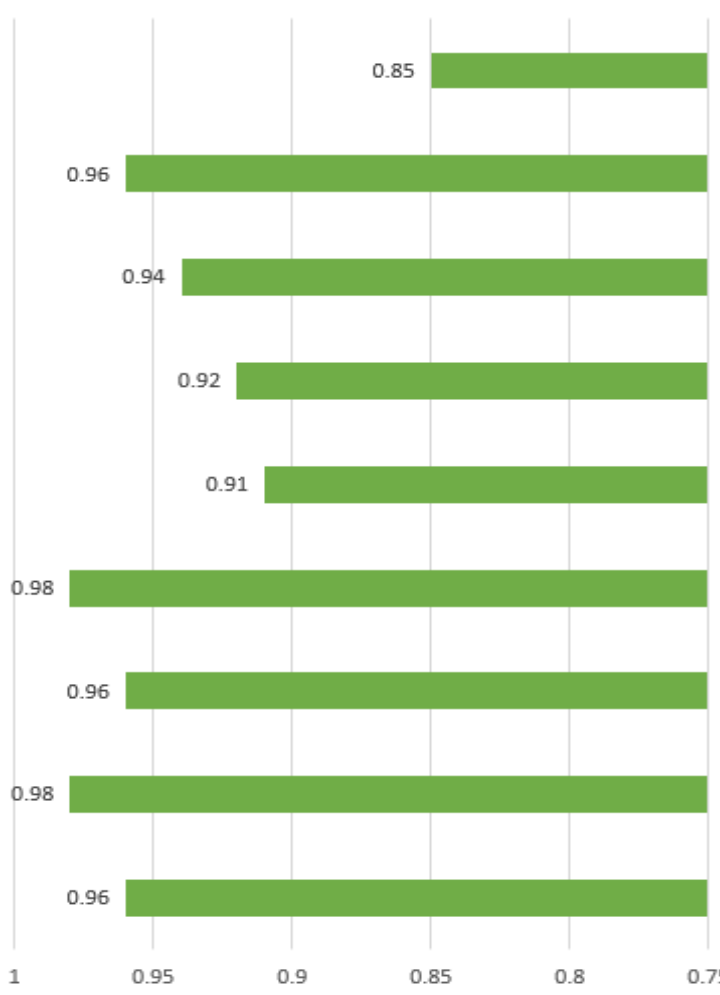

Study Conclusions:

In the light of discussing the study results, researcher found the following conlcusions:

- $\quad$ The manual procedures for the Executive Plan can be transferred into electronic mechanisms through the designed web application,

- $\quad$ The designed web application is valid to be applied for the Physical Education College (boys) Executive Plan,

- $\quad$ The designed web application saves time and effort for the users to input, monitor, and follow up on the plan's goals and activities,
Do you believe in case of electronic application trial success in Executive plan E-Management for Physical Education College(men) Alexandria University strategy it can be published and generalize an get benefited by other Colleges and institutes in Alexa

Electronic application will provide transparency through the department input for his mission accomplished or not or even postpended end of every quarter year

Accuracy will be one of the Electronic application characteristics by providing by input months of the implementation and percentage 0 . achievement every month

Safety and security will be managed by the Electronic application by assigning a username and password for each user who authorized tc use the application

Electronic application will connect all plan by one network provided by the application.

Departments plan information storage by Electronic application to have access anytime with archiving proof of goals achievement.

Flexibility and possibility to revise and edit electronic application tc enhance effectiveness and efficiency after the application trial.

Plan accessibility will be granted through the Electronic application to all plan details easing plan report printing and performance repor

Electronic application will simplify Plan Input procedure and follow up which will save effort and time.

\section{deviation from College's goals and} objectives because departments' objectives and activities should align with the College's strategic goals, based in each department's specialization,

- $\quad$ The designed web application considered security and confidentiality and assigning different appropriate privileges for each user, secured through use of usernames and passwords,

- $\quad$ The designed web application supports management decision-making for upper management by providing all of the needed data, 
- The designed web application provides an archive of plans with accessibility to all the plan details,

- The designed web application connects all the college departments through a single unifying intranet mechanism,

Recommendations:

- $\quad$ Replace the manual system for the plan with the web application in the all strata of the Executive Plan process,

- $\quad$ Require all College departments use the web application in the planning process,

- Generalize use of the web application throughout all colleges and faculties of Alexandria University,

- Establish a strong technological infrastructure (i,e, fiber-optic internet, computers, communications tools) in the College,

- Encourage researchers to design more applications and electronic solutions aiming to reduce or eliminate entirely manual paper management, thereby increasing efficiency and effectiveness of management in the College of Physical Education through E-Management,
References

Arabic References:

1. Abdussalam Aboukahf \&Alaa El Garbawy \&Mohamed Sultan:

Modern Management Systems(Mangers-OrganizationStrategic planning-decisionscommunication), University Education House ,Alexandria,2011.

2. Ahmed Fathi El Het: EManagement principles, Hamed House publication and distribution ,Amman, 2014.

3. Alaa Abdul Razeq Al Salamy: EManagement,Wail house for publication ,Amman,2006.

4. Ali Alsaid ElBaz: Systems and rules role in E-Management implementation, paper presented in "E-Management between reality and challenges" conference ,Management institute 2003,10-12 May, Masqat ,2003.

5. Asia suleiman \&Farid Cortel: EManagement ,Zamzam publication and distribution,Amman,2015)

6. Bilal Mahmoud Alwadi \&Mahmoud Hussien Alwadi: EManagement and knowledge and contemporary applications, Safaa house for publication and distribution ,Amman,2011.

7. Bin Mohamed Al Hassan: EManagement as a method for managing Localities in Kingdom of Saudi Arabia Practical study on Al Riyad ,Master's thesis, Om 
dorman university, Om Dorman,2009.

8. Fayeq Hosny Abouhalema: Modernity in Sports Management ,Vol1,Wael for publication and distribution,Amman,2004.

9. Hammad Al Fateh: EManagement role in in organization improvement(Survey study on Police officers east zone),Master's thesis ,Naif Arab University for Security Sciences,Al Riyad,2008.

10. Hussein bin Mohamed: EManagement between Theory and Practice, paper presented to international conference for management development,King Abdul Aziz Public library,Al Riyad,2009.

11. Hussein bin Mohamed Al Shaqsi: Proposed project for EManagement implementation in ministry of High Education in Sultanate of Oman in the scope of staff, Master's thesis, Faculty of Education,Masqat,2008.

12. Masoud bin Mohamed Alnemr \&others: General Mangement:foundation and functions,volume 4,Al Farazdaq commercial printing ,Al Riyad,2006.

13. Mohamed Ahmed ouda ALagha: The Degree of E-management employment In Palestinian University in Gaza Governate and relation to Quality of Services presented to students, Faculty of Education Islamic University,Gaza,2012,
14. Mohamed Al Ghassany: "EManagement", Digital Magazine ,volume 1,amman, 2005.

15. Mohamed Ali Alshahry: EManagement affect on Staff performance level: Practical study in Tabok university, Master's Thesis , Moata University,Amman, 2011.

16. Mohamed Souror Alhariry: General Management,Al Manahageya house publication and distrubtion, Al Riyad,2016.

17. Mostafa Yousef Alkafi; EManagement ,house of Raslan organization publication distribution, Damascus, 2012.

18. Raft Radwan: E-Management, information center and decision making minster's councel,Cairo,2004.

19. Saad Ghalb Yasin: EMangement,Al Yazory house publication distribution ,Amman,2010.

20. Said Gondb Almalawy \& Saleh Gondb Almalawy: Strategic Planning in modern management, Obekan publication distribution, Al Riyad,2019.

21. Salem Mohamed Al halafawy: Education Technology innovations in information era, $\mathrm{Al}$ Fakr Hous publication distributin,Amman,2006.

22. Wael Mohamed Idres \&Dahir Al Galbi: Strategic Management Concepts and operations, Wael House for publication distribution ,Amman,2011. 
English Reference:

23. Aldejwi , Sami Fathi:Theory and practice: Compliance with best practices in Saudi Arabian public universities' strategic planning, D,P,A, California, University of La Verne, United States, 2014.

24. Alsaady, Abdulkhudar: Planning strategy and the use of information technology in higher education: A comparative analysis of two universities in Michigan, PH,D, Minnesota Capella University, united states, 2007.

25. Charles W, L, Hill \&Gareth R, Jones: Stragegic Management Cases, Vol, 10, Mason, SouthWestern Cengage Learning, USA,2013.

26. Cho, Yonghee: Exploring Technology Forecasting and Its Implications for Strategic Technology Planning, Doctor of Philsophy, Portland: Portland State University, 2018.

27. Gouge, Ian: e-Management the Impact of e-Business Today IT Manager, Spinger-Verlag london limted, London, 2003.

28. Irving Rein,Ben Shields,Adam Grossman: The Sports Strategist Developing Leaders for a HighPerformance Industry, Oxford University press, New York,2015.

29. Kohei Kogiso, Daichi Oshimi , Munehiko Harada : Sports Management and Sports Humanities, Springer Tokyo Heidelberg, Japan, 2015.

30. oke, lorne Dougllas: Planning for information technology in the small college, Doctor of education, Ann Arbor, United states, 2003.

31. Salter, Robert Lawrence: Two Case Studies of the University Strategic Planning Process, Ed,D, University of Lindenwood, Missouri,United States, 2014. 
